\title{
MODELLING SUBALPINE FOREST DYNAMICS AS INFLUENCED BY A CHANGING ENVIRONMENT
}

\author{
N. KRÄUCHI \\ Chair of Forest Sciences, Swiss Federal Institute of Technology, ETH-Zentrum, CH-8092 Zürich \\ F. KIENAST \\ Swiss Federal Institute for Forest, Snow and Landscape Research, CH-8903 Birmensdorf
}

\begin{abstract}
FORSUM, a forest succession model of the JABOWA/FORET type was applied to simulate possible impacts of environmental changes on subalpine forest ecosystems and compared with the model FORECE (Kienast, 1987). The model used is based on approaches of Botkin et al. (1972), Shugart (1984) and Kienast (1987) and has been improved by implementing soil water movement calculations based on a user-defined one-dimensional nonhomogeneous soil profile. The influence of a possible climatic change on subalpine ecosystems was investigated for three different sites in the Grisons (Switzerland). The scenarios used are based on climate change predictions of General Circulation Models. A temperature increase of $3^{\circ} \mathrm{C}$ would cause important changes in species composition. Deciduous trees would invade today's subalpine belt causing a displacement of various conifers in this zone. Some coniferous species might eventually migrate into today's alpine zone which would consequently become afforested. Comparing the vegetation changes as predicted by the model FORSUM and FORECE we found that the models generate the main general patterns. However under global warming and a concurrent precipitation decrease total biomass production seems to be overestimated by FORECE. Information about seed dispersal rates (horizontal and vertical), seed availability and soil formation processes should be implemented in these models to improve the reliability of the predictions.
\end{abstract}

\section{Introduction}

We are living in a changing environment and one of the changes occurring due to human activities is the increase of greenhouse gases in the atmosphere. Since 1958 concentrations of $\mathrm{CO}_{2}$ at the Mauna Loa observatory in Hawaii have increased from 312 to 352 ppm (Siegenthaleret al., 1988; Keeling et al., 1989), and global mean-surface air temperature has increased over the past 100 years by $0.3-0.6^{\circ} \mathrm{C}$. Geologic data taken from ice cores in the Antarctic and Greenland show a strong correlation between temperature and atmospheric concentration of carbon dioxide and methane (Lorius, 1989). A warming ol $0.4^{\circ} \mathrm{C}$ is threc times larger than the standard deviation of annual mean temperatures in the 30-year climatology. Thus, it can be stated with about $99 \%$ probability confidence that current temperatures represent a real warming trend rather than a chance fluctuation over the past 30-year period (1951 - 1980) (Bruck, 1990). However Slingo (1989) states: "The fact that 14 differentmodels give 14 different answers for cloud feedback, show that we are far from the goal of accurate predictions of future climate change (...) it will be several years before reliable predictions of global and regional climate change are available from the models". General circulation models indicate a temperature increase of $3^{\circ}$ to $4^{\circ}$ Celsius due to a $\mathrm{CO}_{2}$ doubling (Houghton

Water, Air, and Soil Pollution 68: 185-197, 1993.

(C) 1993 Kluwer Academic Publishers. Printed in the Netherlands. 
etal., 1990). $3^{\circ} \mathrm{C}$ warming would confront natural systems with a warmer world than has been experienced in the past $100^{\circ} 000$ years (Schneider \& Londer 1984 ). $4^{\circ} \mathrm{C}$ would make the earth its warmest since the Eocene,40million years ago (Webb, 1990). The warming would bevery fast compared to recent warmings (15-40 times faster, Gleick et al., 1990). If temperature will change as fast as predicted animals and plants need to adapt within the life span of individual trees instead of over several generations of trees. However it is unclear how species change their ecophysiological characteristics under higher $\mathrm{CO}_{2}$ concentrations and thus might colonize unknown niches (Blum, 1991). When climate warms, species shift upward if the environmental factors remain suitable for the species. Generally, a short rise in altitude corresponds to a major shift in latitude. The $3^{\circ} \mathrm{C}$ cooling of $500 \mathrm{~m}$ in elevation equals roughly $250 \mathrm{~km}$ in latitude (MacArthur, 1972). To predict possible impacts of environmental changes concerning forest ecosystems we may use simulation models. In this report they are used to evaluate the influence of biotic and anthropogenic factors on the development of subalpine forests in Central Europe.

Over the past 30 years there has been an astonishing development of computer models designed to simulate ecological processes, to examine theories of succession and to assess the effects of growth modifying factors on species composition of forest communities. There are three basic types of forest simulators: (a) tree models, taking the individual tree as the basic unit of the model; (b) gap models, simulating growth of individual trees on a prescribed spatial area; and (c) forest models, considering the forest as basic entity. For a more detailed review of ecological model approaches see Shugart (1984). We can further distinguish between stochastic and deterministic models. For a deterministic simulation the output is exactly determined for a given input. In a stochastic model the output for a given input can't be exactly predicted, since the output itself is a stochastic variable.

\section{Model Approach}

The simulation model FORSUM (FOrest SUccession Model) belongs to the family of gap models. The model used in this paper is based on approaches of Botkinet al. (1972), Shugart (1984) and Kienast (1987). It has been improved by implementing various subroutines to calculate the hydraulic cycle, deer browsing, biomass production by assoriments and management practices. Growth, death and establishment of individual trees ( 31 species) is simulated on many small forest plots (Figure 1). By aggregaling these plots forest development on a regional scale may be obtained. This approach is supported by many plant succession studies showing that forest ecosystems can be described as a statistical population of plots with different successional stages (Bray, 1956). Figure 2 exhibits this principle comparing the stem distribution by diameter classes for single gaps and for the whole stand in a subalpine forest after a simulation of 200 years. Diagram a and $b$ represent the stem distribution on two plots at the same time ( $t$ ) but with different successional stages. Figure $2 \mathrm{c}$ shows the averaged stem distribution at time step $(\mathrm{t})$, indicaling a sufficient regeneration and a decreasing number of trees belonging to upper diameler classes. Stand development of each forest plot is considered a Markovian process with a transformation matrix containing stochastic and deterministic components. Establishment and death of trees, deer browsing and temporal variations of climatic patterns are calculated stochastically; optimal growth, water availability, and light attenuation through the canopy deterministically. Forest succession is driven by extrinsic and intrinsic variables (Solomon, 1986). Extrinsic variables to the stand are spring frost, browsing and summer warmth. Intrinsic variables to the stand are shading, crowding and interception, whereas potential growth rate and mortality are intrinsic to the species . Each model run starts with either a randomly selected cohort of seedlings in a gap or with a defined species and diameter distribution to simulate tree establishment. Unfavourable environmental factors and site conditions control the exclusion of species from the seed pool. Growth of each individual tree is simulated by decreasing the maximal potential growth rate at its respective age by 
factors being most limiting, according to Liebig's Law (Liebig, 1840).

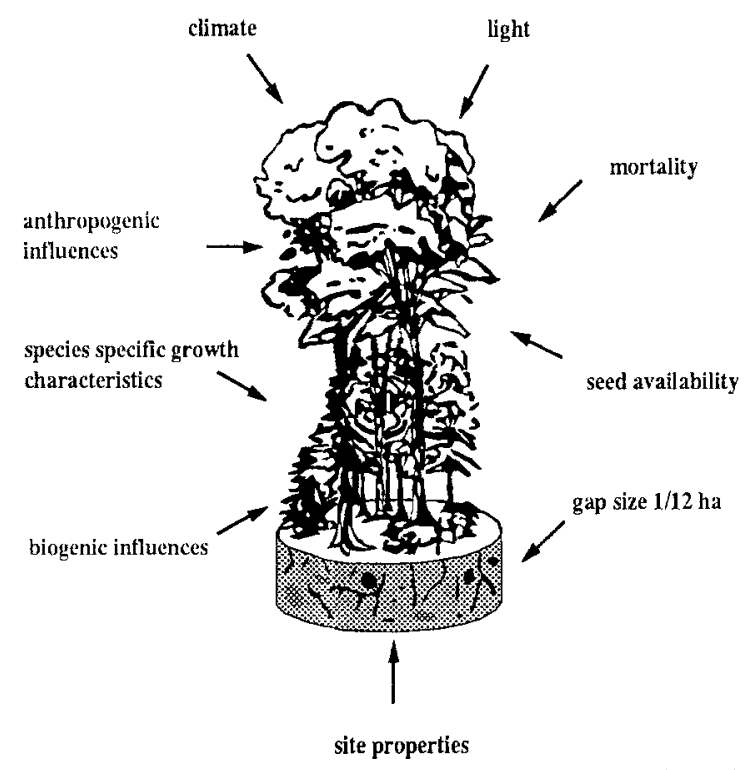

Figure 1: Factors controlling growth and competition on a plot of the FORSUM forest succession model

The theoretical growth equation has a quasilogistic form, and is based on the assumption that biomass increment in one year is positively correlated with the amount of sunlight the leaves receive (Botkin et al., 1972; see also Shugart \& Prentice, 1992). Death of individual trees is determined with a mortality function which allows only $1 \%$ of all trees to reach the maximal physiological age. Trees are also rated as dead, if they are growing slower than specified by the user.
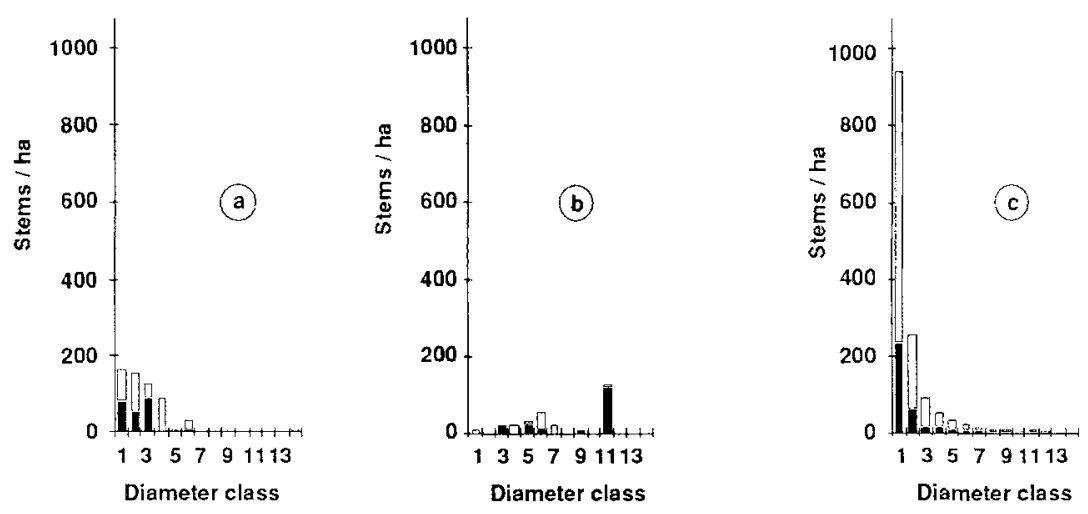

\section{deciduous trees \\ coniferous trees}

Figure 2: Frequency distribution showing number of simulated trees in a subalpine forest by 8-cm diameter classes. The principle of the gap model is to average the results of single gaps $(a, b)$ to obtain forest succession on a regional scale (c). (a\&b: single gaps, $c$ : average of 100 gaps). 
The individual species' data for light and soil moisture requirements, maximal age, etc., were derived from silvics book and mensuration data (Mitscherlich, 1978; Ellenberg, 1986; Leibundgut, 1984). The soil moisture requirements are based on ecograms as shown in Figure 3. They were taken from Ellenberg (1986) and Leibundgut (1984) For all species considered in the current model physiological amplitude and physiological optimum were parameterized and used to determine whether actual site conditions allow species establishment and growth on a specific site.

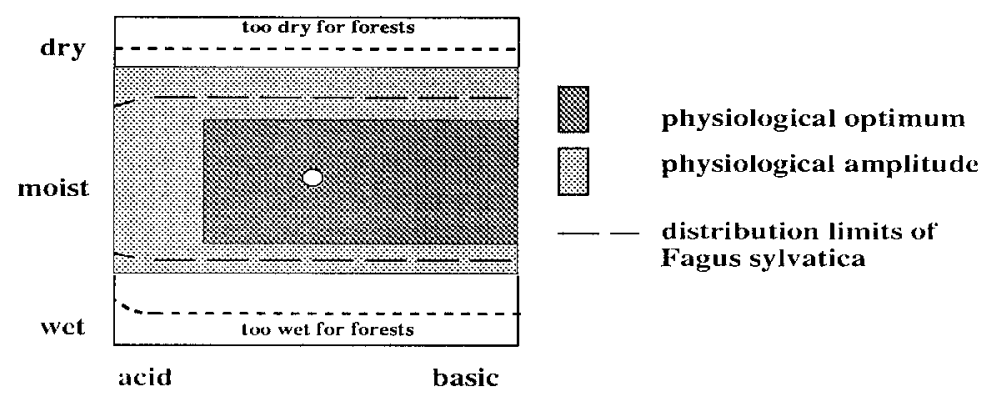

Figure 3: Ecogram of Quercus petraea as used for species parameterization

The main parameters which determine the growth functions of the individual species are listed in Table 1 together with those of FORECE (Kienast, 1987). Tree establishment is favoured, if the site conditions match the optimal or potential range of a species. The availability of water for plant uptake depends on the water-storing properties of the soil. FORSUM calculates water movement in a one-dimensional nonhomogeneous soil profile considering soil properties, root water extraction, drainage and rainfall (including interception).

\subsection{CLIMATE SIMULATOR}

Precipitation and temperature data are calculated using long time precipitation and temperature records. The random temperature and precipitation values are distributed normally around the mean value of each month. Soil moisture variations are calculated on a daily base. Simulation runs have shown that uniformly distributed daily water input would lead to an overestimation of the real soil water content and an underestimation of the actual water stress. Thus the rainfall pattem is stochastically simulated using the number of days with more than $1 \mathrm{~mm}$ precipitation for that specific site. Temperature and rainfall are calculated independently, since comparison of temperature and precipitation records have not shown a correlation between monthly temperature and precipitation at different sites in Switzerland $\left(0.02 \leq \mathrm{r}^{2} \leq 0.39\right)$. Rainfall interception is considered in the model by using an allometric function. Interception depends upon rainfall intensity and canopy structure. The model is based on the assumption that all deciduous trees behave like Fagus sylvatica and all conifers like Picea abies. Interception rates vary between 0 and $80 \%$ depending on the forest composition and precipitation intensity (Table 2). The interception decreases proportionally with increasing percentage of deciduous trees and increasing rainfall intensity (Lange et al., 1976). 
Table 1

Species parameters as used in FORSUM and (in brackets) FORECE to determine growth function of the 31 species considered

\begin{tabular}{lccc}
\hline Species & $\begin{array}{c}\text { Maximal diameter } \\
{[\mathrm{cm}]}\end{array}$ & $\begin{array}{c}\text { Maximal height } \\
{[\mathrm{cm}]}\end{array}$ & $\begin{array}{c}\text { Maximal age } \\
\text { [years] }\end{array}$ \\
\hline Abies alba & $180(150)$ & $6000(6000)$ & $600(800)$ \\
Larix decidua & $200(150)$ & $5100(5400)$ & $950(700)$ \\
Picea abies & $150(120)$ & $5500(5000)$ & $600(1000)$ \\
Pinus cembra & $200(200)$ & $2300(2300)$ & $1000(1200)$ \\
Pinus mugo & $80(80)$ & $1400(1000)$ & $500(500)$ \\
Pinus strobus & $180(200)$ & $5300(6500)$ & $250(500)$ \\
Pinus sylvestris & $110(110)$ & $4500(4800)$ & $600(600)$ \\
Pseudotsuga menziesii & $180(200)$ & $6500(8000)$ & $600(1000)$ \\
Taxus baccata & $90(50)$ & $1600(1500)$ & $1500(1500)$ \\
Acer campestre & $65(70)$ & $1900(1500)$ & $120(200)$ \\
Acer platanoides & $80(100)$ & $2500(2500)$ & $170(400)$ \\
Acer pseudoplatanus & $200(200)$ & $3200(3000)$ & $500(600)$ \\
Alnus glutinosa & $55(50)$ & $2800(3000)$ & $120(300)$ \\
Alnus incana & $40(40)$ & $1700(2000)$ & $80(100)$ \\
Alnus viridis & $20(40)$ & $350(250)$ & $100(150)$ \\
Betula pendula & $60(65)$ & $3000(3000)$ & $120(120)$ \\
Carpinus betulus & $80(100)$ & $2700(2000)$ & $180(250)$ \\
Castanea sativa & $250(200)$ & $3500(2500)$ & $1000(800)$ \\
Fagus sylvatica & $170(150)$ & $4300(3500)$ & $400(350)$ \\
Fraxinus excelsior & $180(170)$ & $4000(3500)$ & $300(250)$ \\
Populus nigra & $200(200)$ & $3200(2500)$ & $250(300)$ \\
Populus tremula & $150(100)$ & $2800(2000)$ & $150(150)$ \\
Quercus petraea & $240(180)$ & $4000(4000)$ & $900(700)$ \\
Quercus pubescens & $100(100)$ & $2500(2000)$ & $600(600)$ \\
Quercus robur & $250(200)$ & $4200(4000)$ & $1000(1000)$ \\
Salix alba & $200(100)$ & $2800(3000)$ & $200(150)$ \\
Sorbus aria & $40(30)$ & $1500(1200)$ & $200(200)$ \\
Sorbus aucuparia & $40(40)$ & $1600(1700)$ & $120(120)$ \\
Tilia cordata & $300(300)$ & $3000(2500)$ & $1000(800)$ \\
Tilia platyphyllos & $300(300)$ & $4000(3300)$ & $1000(800)$ \\
Ulmus glabra & $120(60)$ & $3500(3000)$ & $450(400)$ \\
\hline & & & \\
\hline
\end{tabular}

\subsection{SOIL WATER AVAILABILITY}

The availability of water depends on the water-storing properties of the soil and on the net precipitation input. Gap models like FORECE use a simple soil/water evapotranspiration approach defining the soil water available for plants as the difference between the amount of soil water at field capacity and that at the wilting point. The potential evapotranspiration 'PET' is calculated in FORSUM using the formula of Thomthwaite and Mather (1957), and the soil compartment is represented by a one-dimensional nonhomogeneous soil profile (Figure 4). The profile is divided into maximal 10 layers having different chemical $(\mathrm{pH})$ and physical properties $(\mathrm{k}(\Theta))$. The properties of a specific site can be obtained by comparing [management by analogy] each horizon with reference soils (Richard et al., 1978-87). In the current version of FORSUM the horizons of twenty-three different soil types are characterized by soil water release curves and saturated water conductivity. Soil water availability is calculated for each day and considers root water extraction, drainage and canopy throughfall. 
Table 2:

Interception matrix used in FORSUM to determine actual precipitation input into the soil

\begin{tabular}{|c|c|c|c|c|c|c|c|c|c|}
\hline $\begin{array}{c}\text { Rainfall } \\
\text { [mm] }\end{array}$ & $0-1$ & $1-2$ & $2-3$ & $3-5$ & $5-10$ & $10-15$ & $15-20$ & $>20$ & \\
\hline Picea & \multicolumn{8}{|c|}{ Interception in $\%$ of total precipitation [\%] } & Fagus \\
\hline $100 \%$ & 82 & 63 & 55 & 47 & 33 & 30 & 26 & 24 & $0 \%$ \\
\hline $90 \%$ & 81 & 62 & 52 & 44 & 31 & 29 & 25 & 23 & $10 \%$ \\
\hline $80 \%$ & 80 & 61 & 49 & 41 & 30 & 27 & 24 & 23 & $20 \%$ \\
\hline $70 \%$ & 79 & 61 & 46 & 38 & 28 & 26 & 23 & 22 & $30 \%$ \\
\hline $60 \%$ & 78 & 60 & 43 & 35 & 26 & 24 & 22 & 22 & $40 \%$ \\
\hline $50 \%$ & 77 & 59 & 40 & 33 & 25 & 23 & 22 & 21 & $50 \%$ \\
\hline $40 \%$ & 76 & 58 & 37 & 30 & 23 & 22 & 21 & 20 & $60 \%$ \\
\hline $30 \%$ & 75 & 57 & 34 & 27 & 21 & 20 & 20 & 20 & $70 \%$ \\
\hline $20 \%$ & 74 & 57 & 31 & 24 & 19 & 19 & 19 & 19 & $80 \%$ \\
\hline $10 \%$ & 73 & 56 & 28 & 21 & 18 & 17 & 18 & 18 & $90 \%$ \\
\hline $0 \%$ & 72 & 55 & 25 & 18 & 16 & 16 & 17 & 18 & $100 \%$ \\
\hline
\end{tabular}

The root extraction term $S$ depends only on the soil water pressure head $\boldsymbol{h}$ and a maximal extraction rate $S_{m}$ as follows (Van Genuchten, 1986):

$$
\mathrm{S}=\alpha(\mathrm{h}) * \mathrm{Sm}
$$

Assuming that water and salinity stress have similar effects on the rate of transpiration, the following dimensionless water stress function $\alpha(\boldsymbol{h})$ is used, where $\boldsymbol{h 5 0}$ (pressure head at which the extraction rate is reduced by $50 \%)$ and $p(=3)$ are empirical constants:

$$
\alpha(h)=\frac{1}{\left(1+\left(\frac{h}{h 50}\right)\right)^{p}}
$$

with the maximal extraction term $S_{m}$ as a function of the potential evapotranspiration (PET) and $\lambda(z)$ of the form

$$
\operatorname{Sm}(\mathrm{z})=\mathrm{PET}^{*} \lambda(\mathrm{z}) \quad\left[\mathrm{T}^{-1}\right]
$$

where $\lambda(z)$ is a depth dependent root distribution function of the form

$$
\lambda(\mathrm{z})=\left\{\begin{array}{cc}
\frac{5}{3} \cdot \mathrm{L} & \mathrm{z} \leq 0.2 \mathrm{~L} \\
\frac{25}{12} \cdot \mathrm{L} \cdot\left(1-\frac{\mathrm{z}}{\mathrm{L}}\right) & 0.2 \mathrm{~L}<\mathrm{z}<\mathrm{L} \\
0 & \mathrm{z} \geq \mathrm{L}
\end{array}\right.
$$


The functional forms of the hydraulic properties are those of Van Genuchten (1986):

$$
\begin{aligned}
& \Theta=\Theta r+\frac{(\Theta s-\Theta r)}{\left[1+(\alpha \mid h l)^{n}\right]^{m}} \\
& \mathrm{k}\left(\mathrm{s}_{\mathrm{e}}\right)=\mathrm{k}_{\mathrm{S}} \sqrt{\mathrm{se}_{\mathrm{e}}}\left[1-\left(1-\mathrm{se}^{1 / \mathrm{m}}\right)^{\mathrm{m}}\right]^{2} \quad s_{e}=\frac{\Theta-\Theta_{r}}{\Theta_{s}-\Theta_{r}} \quad m=1-\frac{1}{\mathrm{n}}
\end{aligned}
$$

where $\Theta_{r}\left[\mathrm{~cm}^{3} / \mathrm{cm}^{3}\right]$ and $\Theta_{s}\left[\mathrm{~cm}^{3} / \mathrm{cm}^{3}\right]$ are the residual and field saturated volumetric water contents, respectively; $\boldsymbol{k}_{s}[\mathrm{~cm} /$ day $]$ is the saturated hydraulic conductivity, $s_{e}\left[\mathrm{~cm}^{3} / \mathrm{cm}^{3}\right]$ is the reduced water content and $\boldsymbol{a}$ and $\boldsymbol{n}$ are empirical constants determining the shape of the hydraulic functions.

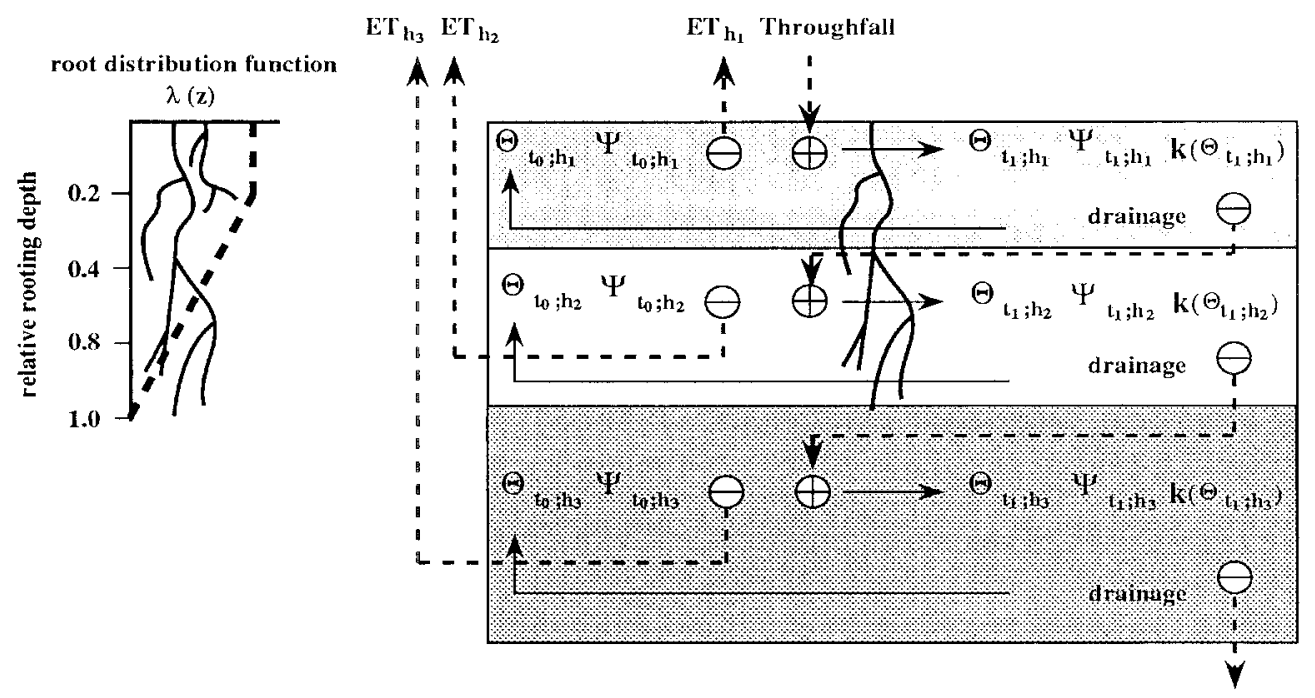

Figure 4: One-dimensional, nonhomogeneous soil profile as used to calculate the hydrologic properties in FORSUM: $k(\Theta)$ : unsaturated hydraulic conductivity [cm/day]; $\Theta:$ water content $\left[\mathrm{cm}^{3} / \mathrm{cm}^{3}\right] ; \Psi$; water potential [Pa]; ET: evapotranspiration [cm/day]

Verification runs for the soil part were conducted for two different soils. The soil moisture characteristics were measured over a period of 5 months in a beech and a pine forest of the Swiss Central Plateau. The pressure head was measured with stationary tensiometers at four different soil depths (10, $35,80,140 \mathrm{~cm}$ ), the water content with a neutron moisture meter. The experimental sites were covered with a plastic roof $\left(100 \mathrm{~m}^{2}\right)$ to exclude precipitation input into the soil. Simulation runs for these sites have shown a good coincidence with the actual desorption behaviour of these soils $\left(0.691<\mathrm{r}^{2}<0.971\right)$. 


\subsection{BIOMASS CALCULATION}

In addition to the common biomass calculation (i.e. FORECE) a subroutine was implemented to calculate biomass by tree components (wood and bark). It is based on the assumption that all coniferous species grow similarly to white spruce (Picea glauca) and all deciduous trees like balsam poplar (Populus balsamifera). The regressions are based on a detailed Canadian investigations (Singh,1982). They were incorporated with regard to a future implementation of nutrient cycling rather than estimation of production. The root biomass is calculated either by a regression function or by using an above/below ground ratio. The relationship between above and belowground biomass has been derived from Duvigneaud et al. (1971), Ruark \& Bockheim (1989), Whittakeret al. (1974), and Ovington (1957). The regression is valid for above ground biomass (agb) greater than $25 \mathrm{t} / \mathrm{ha}$. Between 15 and $25 \mathrm{t} / \mathrm{ha}$ or below $15 \mathrm{t} / \mathrm{ha}$, below ground biomass equals $0.45 * a b g$, and $0.60 * a g b$ respectively.

\section{Possible Impacts of Climate Change on Subalpine Forest Ecosystems}

The simulation runs were conducted for two different sites in the Grisons (Bever and Scuol). They considered only the indirect $\mathrm{CO}_{2}$ induced temperature increase, not the concurrent direct $\mathrm{CO}_{2}$ fertilizing effect and potentially $\mathrm{CO}_{2}$ induced changes in the ecophysiological amplitude of the species. All simulation runs started with a given species composition corresponding to the present one. The soil type on both sites is a podzol (Ah, E, (Bh), (S)Bfe) with a rooting depth of $60 \mathrm{~cm}$. The simulation experiment was conducted for 80 replicates each. Stand, species and tree specific data are provided through time in intervals of twenty years.

Scuol:

$1495 \mathrm{~m}$ asl.

mean annual temperature :

$3.95^{\circ} \mathrm{C}$

mean annual rainfall:

$793 \mathrm{~mm}$

Bever:

$1712 \mathrm{~m}$ asl. mean annual temperature:

$1.50^{\circ} \mathrm{C}$

mean annual rainfall:

$842 \mathrm{~mm}$

Scenario assumption: $\mathrm{CO}_{2}$ - doubling results in a temperature increase of $3^{\circ}$ Celsius (March November), respectively $3.5^{\circ}$ Celsius (December - February).

The climatic conditions in Scuol are less continental than in Bever. This results in a different forest succession under today's climatic conditions. Excluding human intervention the forest simulator generates a forest dominated by Larix decidua, Pinus cembra and Picea abies. Starting at year 2100 biomass of Picea abies is beginning to decrease while Pinus cembra becomes more competitive. This is due to the continentality of the site which is to high for Picea abies. Assuming increased $\mathrm{CO}_{2}$ concentrations and increased precipitation $(+10 \%)$ significant changes in species composition start as early as 40 years after the climatic conditions are assumed to change. Especially Fagus sylvatica and Pinus species are more competitive. These changes are mainly caused by the increased water stress during the vegetation period. Total biomass does not change significantly.

Figure 5 displays the forest development under a 'business as usual' scenario in Scuol. The forest is characterized by an increasing dominance of Picea abies. The climate in Scuol is less continental than in Bever and therefore more favourable for Picea abies. This results in the disappearance of Pinus cembra. The run presented in figure 6 is exploring changes that might occur under the 
influence of a temperature increase due to $\mathrm{CO}_{2}$ doubling and a precipitation increase of $10 \%$. The diagram shows a complete disappearance of Pinus cembra within 50 years. Under increasing degree day sums species like Fagus sylvatica, Acer pseudoplatanus, Abies alba and Sorbus aucuparia become more competitive. The significant initial loss of total biomass has disappeared by the year 2100. The difference between the total biomass at the beginning (yr. 2000) and that at the end (yr. 2400 ) of the simulations is not significant (even for scenarios with a precipitation decrease of $20 \%$ ). The same simulation experiments have been conducted with the model FORECE (Kienast, 1987), but with the species parameters of FORSUM (Table 1). The result of this investigation is presented in Figure 7. Biomass production does not change significantly with increased temperatures as long as precipitation is not decreasing. However a simultaneous precipitation deficit results in a significant lower biomass production for that specific subalpine site (Untervaz, Grisons). The different results are most probably due to the different methods used to calculate water supply and water stress in FORECE and FORSUM. Soil water availability is probably underestimated in FORECE for a soil of the podzol type (Kräuchi, in print).

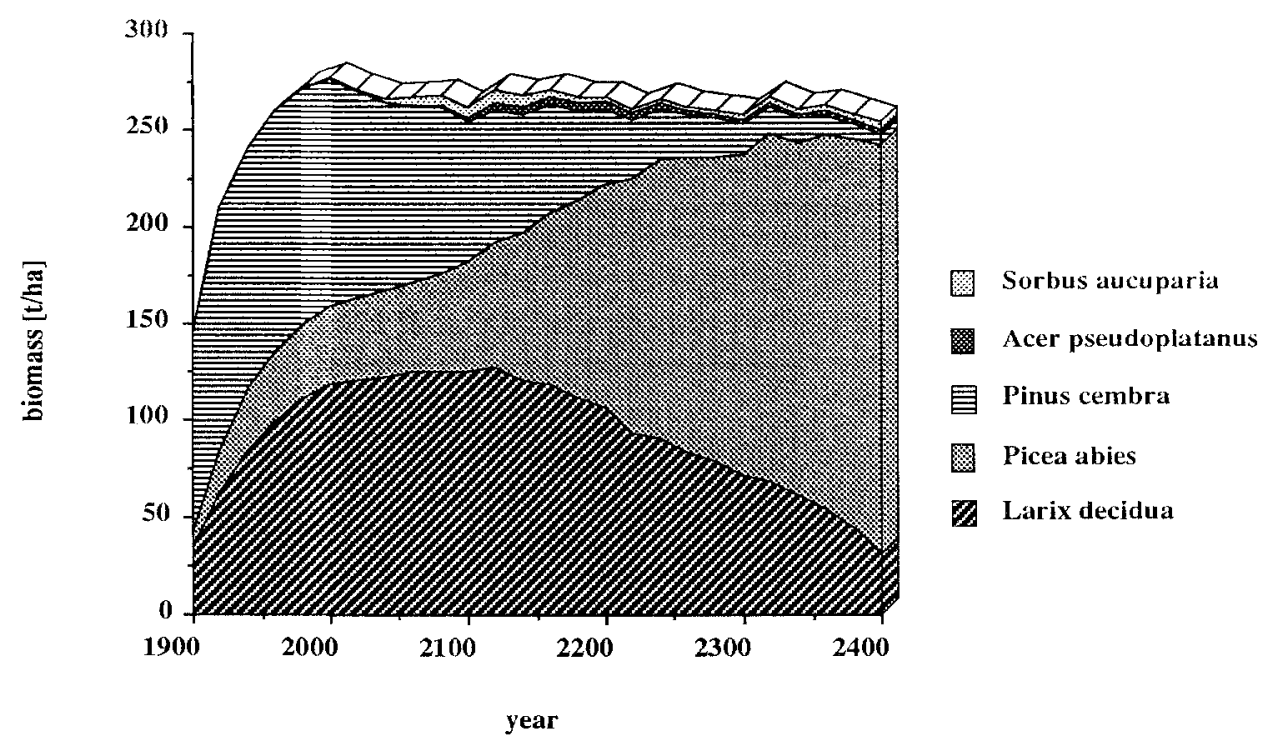

Figure 5: Scuol: Forest development without temperature increase.

The simulations have shown that a global warming would cause important changes of the species composition. Deciduous trees would invade today's subalpine belt. Various conifers would be displaced and migrate into today's alpine zone which would become afforested. Dieback of certain species will cause at least a short-term biomass decline influencing ecosystem stability and causing higher risks of avalanches and landslips. Immigration rates of species not growing in today's subalpine zone are probably overestimated in FORSUM and in FORECE since these forest simulators do not consider seed dispersal rates (vertical) and seed availability (spatial). 


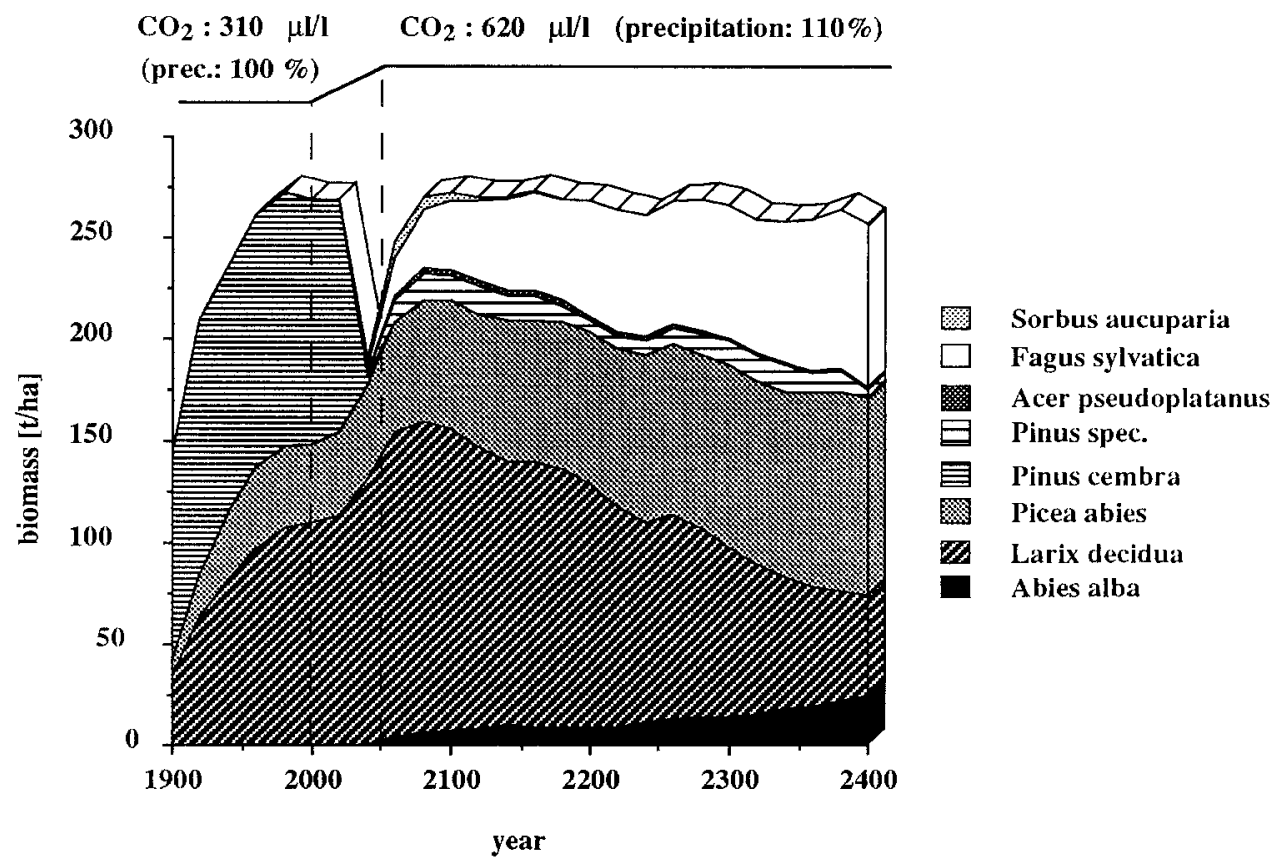

Figure 6: Scuol-Scenario: Doubling of $\mathrm{CO}_{2}$ between yr. 2000 and yr. 2050 and concurrent precipilation increase by $10 \%$. Temperature and precipitation increase linearly .

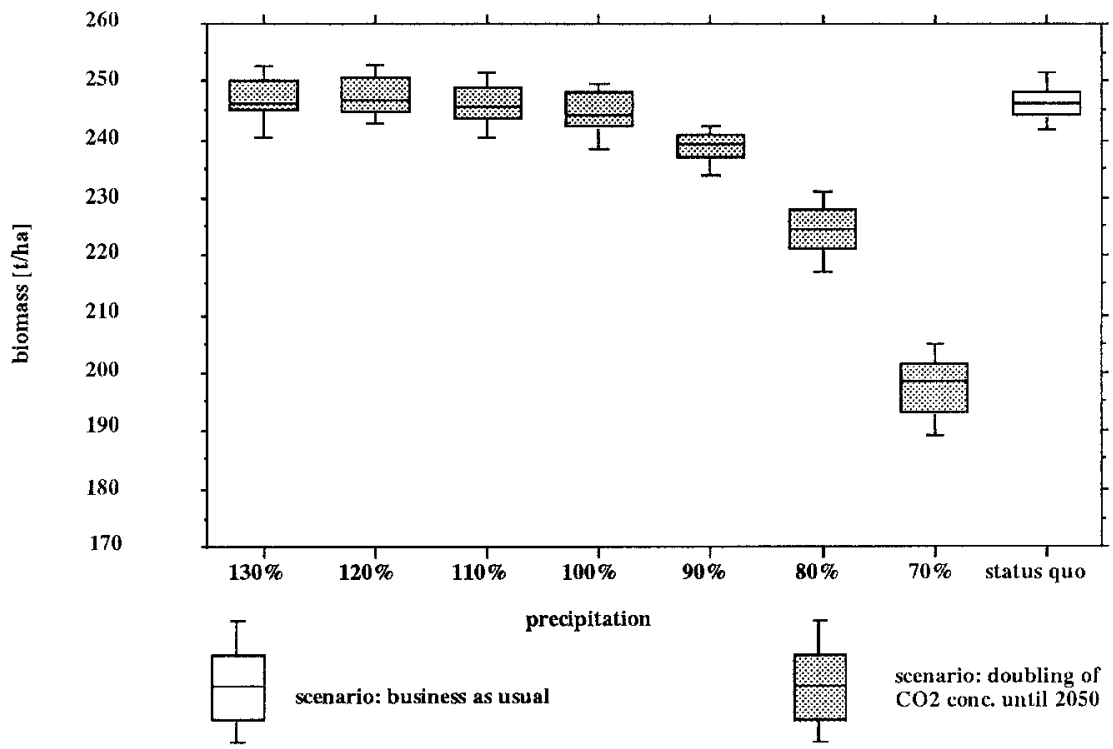

Figure 7: Influence of hypothesized global warming and precipitation changes on biomass development of a subalpine spruce forest in the Grisons (Untervaz). Calculations with FORECE but species parameters of FORSUM. 


\section{Discussion:}

A doubling of the present atmospheric $\mathrm{CO}_{2}$ concentration is likely to occur by the middle of the next century and there may be major change in temperature and precipitation that will affect tree growth. The ranges of the ecosystems move when the climatic pattern change but if the climate changes as fast as predicted many species would not be able to migrate fast enough. The simulations have shown that a global warming would cause important changes of the species composition in subalpine forests. Deciduous trees would invade today's subalpine belt. Various conifers would be displaced and migrate into today's alpine zone which consequently would become afforested provided that the soils are suitable for tree growth. The model simulations are based on many simplified relevant factors. However some parameters are not yet included in the model such as changes in the ranges and severity of pathogens, changes in competitive interactions, and additional effects of nonclimatic stresses as acid rain. The accuracy of the forest succession models may be further improved by implementing important succession factors as seed dispersal rates (horizontal and vertical) or by considering tree species that are currently not present in our region but potentially capable to grow under changing environmental conditions (Laurus laurocerasus, Eucalyptus spec.) The present model can be used to simulate secondary forest succession on specific sites, however it must be improved to predict primary succession on weakly or non -developed soils. Since soil formation processes will probably be the limiting factors of species migration towards the alpine vegetation belt information about soil genesis needs to be incorporated into the model, Many factors and synergisms remain unknown and we have to remain open-minded. It is very important to maintain the biological diversity of the forest ecosystems to allow for a wide variety of possible developments.

\section{References}

Blum, H., 1991: Treibhauseffekt und Pflanzenwachstum. Vierteljahresschrift der Naturforschenden Gesellschaft in Zürich 136/4:189-206.

Botkin, D. B., Janak, J.F., Wallis, J. R., 1972: Some ecological consequences of a computer model of forest growth. J. Ecol., 60: 849-872.

Bray, J. R., 1956: Gap-phase replacements in a maple-basswood forest. Ecology 37: 598 - 600.

Bruck, R. I., 1990: Global Climate Change and Biodiversity. In: Proceedings Global Climate Change Symposium, College of Agriculture and Life Sciences, April 9 1990, Raleigh, NC.

Duvigneaud, P., Kestemont, P., Ambroes, P., 1971:Productivité primaire des forêts tempérées d'essences feuillues caducifoliées en Europe occidentale. İn: UNESCO 1971. Productivité des écosystèmes forestiers. Actes Coll. Bruxelles 1969. (Ecologie et conservation,4).

Ellenberg, H., 1986: Vegetation Mitteleuropas und der Alpen in ökologischer Sicht. Verlag Eugen Ulmer, Stuttgart. 989 pp.

Gleick, P. H., Mearns, L., Schneider, S. H., 1990: Climate-change scenarios for impact assessment. In: Peters, R. L., and Lovejoy, T. E. (eds), Proc. World Wildlife Fund. Consequences of the Greenhouse Effect for Biological Diversity, Yale University Press, New Haven.

Houghton, J. T., Jenkins, G. J., Ephraums, JJ. (eds), 1990: Climate change. The IPCC Scientific Assessment, Cambridge University Press, 365 pp.

Keeling, C. D., Bacastow, R. B., Carter, A. F., Piper, S. C., Whorf, T. P., Heimann, M., Mook, W. G., Roeloffzen, H., 1989: A three dimensional model of atmospheric $\mathrm{CO}_{2}$ transports based on observed winds: 1 . Analysis of observational data. In: Aspects of climate variability in the Pacific and the Westem Americas, D. H. Peterson (ed.), Geophysical monograph, 55, AGU, Washington, 165-236. 
Kienast, F., 1987: FORECE - a forest succession model for southern Central Europe. Report ORNL/TM 10575. Environmental Sciences Division. Publication No. 2989, Oak Ridge National Laboratory, Oak Ridge, TN 37830, USA.

Krăuchi, N. (in print): Climate Change - Possible Impacts on Subalpine Forest Ecosystems. In: Proceedings of the First European Symposium on Terrestrial Ecosystems: Forests and Woodlands, Florence, 20 - 24 May 1991.

Lange, O. L., Kappen, L., Schulze, E. D., 1976: Water and Plant Life: Problems and modern approaches. Ecological studies 19, Springer-Verlag, $536 \mathrm{pp}$.

Leibundgut, H., 1984: Unsere Waldbäume, Eigenschaften und Leben. Verlag Huber, Frauenfeld. 168 pp. Liebig, J., 1840: Chemistry and its application to agriculture and physiology. Taylor and Walton, London.

Lorius, C. J., 1989: Polar ice cores and climate. In: Berger, A. (ed.), Climate and Geo-Sciences. Kluwer Academic Publishers, Dordrecht, 77 - 103.

MacArthur, R. H., 1972: Geographical Ecology, Harper \& Row, New York, 269 pp.

Mitscherlich, G., 1978: Wald, Wachstum und Umwelt. Eine Einführung in die oekologischen Grundlagen des Waldwachstums Bd. 1-3. Sauerländer's Verlag, Frankfurt am Main.

Ovington, J.D., 1957: Dry matter production by Pinus sylvestris L. Ann. Bot. n. s. 21287 - 314.

Richard, F., Lüscher, P.,Strobel, T., 1978: Physikalische Eigenschaften von Böden der Schweiz. Band 1 , Sonderserie der Eidg. Anstalt für das forstliche Versuchswesen.

Richard, F., Lüscher, P.,Strobel, T., 1981: Physikalische Eigenschaften von Böden der Schweiz. Band 2 , Sonderserie der Eidg. Anstalt für das forstliche Versuchswesen.

Richard, F., Lüscher, P., 1983: Physikalische Eigenschaften von Böden der Schweiz. Band 3, Sonderserie der Eidg. Anstalt für das forstliche Versuchswesen.

Richard, F., Lüscher, P., 1987: Physikalische Eigenschaften von Böden der Schweiz. Band 4, Sonderserie der Eidg. Anstalt für das forstliche Versuchswesen.

Ruark, G. A., Bockheim, J. G., 1989: Biomass, net primary production, and nutrient distribution for an age sequence of Populus tremuloides ecosystems. Can. J. For. Res. Vol. 18.

Schneider, S. H. , Londer, R., 1984: The Coevolution of Climate and Life. Sierra Club Books, San Francisco, $563 \mathrm{pp}$.

Shugart, H. H. 1984: A Theory of Forest Dynamics. Springer, New York, 278 pp.

Shugart, H.H., Prentice, I.C., 1992: Individual-tree-based models of forest dynamics and their application in global change research. In: Shugart, H.H., Leemans, R., Bonan, G., B. (eds.), A Systems Analysis of the Global Boreal Forest. Cambridge University Press, Cambridge, 313 - 333.

Siegenthatler, U., Friedli, H., Lörtscher, H., Moor, E., Neftel, A., Oeschger, H., Stauffer, B., 1988: Stable isotopes ratios and concentrations of $\mathrm{CO}_{2}$ in air from polar ice cores. Annals of Glaciology, 10.

Singh, T., 1982: Biomass equations for ten major species of the praine provinces. Northem Forest Research Centre (CANADA).

Slingo, A., 1989: Wetter Clouds Dampen Global Greenhouse Warming. Nature 341, 104.

Solomon, A. M., 1986: Transient response of forests to $\mathrm{CO}_{2}$-induced climate change. Simulation modelling experiments in Eastem North America. Oecologia (Berlin), 68:567-579.

Thomthwaite, C.W., Mather, J.R., 1957: Instructions and tables for computing potential evapotranspiraton and the water balance. Publications in Climatology 10:183-311.

Van Genuchten, M. Th., 1986: A numerical model for water and solute movernent in and below the root zone. Model description and user manual. Unpublished Research Report, U. S. Salinily Laboratory, USDA/ARS, Riverside, Califomia.

Webb, T. III, 1990: Past changes in vegetation and climate: Lessons for the future. In: R. L. Peters and Lovejoy, T., E. (eds), Proc. World Wildlife Fund. Consequences of the Greenhouse Effect for 
Biological Diversity, Yale University Press, New Haven.

Whittaker, R. H., Bormann, F. H., Likens, G. E., Siccama, T. G., 1974: The Hubbard Brook Ecosystem Study: Forest Biomass and Production. Ecological Monographs 44. 